\title{
How can surgical continuity be maintained during the COVID-19 pandemic? A quality improvement study in the pre-vaccination period
} \author{
Aziz Ahmet Sürel (D), M. Mahir Özmen ${ }^{3,4,5}$ (D), Erdal Birol Bostancl' (iD \\ ${ }^{1}$ Clinic of Gastrointestinal Surgery, Health of Sciences University Ankara City Hospital, Ankara, Turkey \\ ${ }^{2}$ Clinic of General Surgery, Health of Sciences University Ankara City Hospital, Ankara, Turkey \\ ${ }^{3}$ Department of Surgery, Medical School, Istinye University, Istanbul, Turkey \\ ${ }^{4}$ General Surgery, Liv Hospital, Ankara, Turkey \\ ${ }^{5}$ General Surgery, Ankara Numune Teaching and Research Hospital, Ankara, Turkey
}

Erol Pişkin (D), Muhammet Kadri Çolakoglu ${ }^{1}$ (D), Volkan Öter ${ }^{1}$ (D), Yiğit Mehmet Özgün ${ }^{1}$ (D), Osman Aydın (iD), Alper Güven ${ }^{1}$ (D),

\begin{abstract}
Objective: During the COVID-19 pandemic, most of the elective surgeries had to be postponed. However, it is not possible to delay the surgical treatment of cancer patients for a long time. The aim of this study was to present how gastrointestinal system surgery operations are managed without delay and how employee safety is ensured, together with the results of the last five months. For this purpose, a preclinical and clinical screening system was created.

Material and Methods: Data of the patients who presented to our outpatient clinic between April $1^{\text {st }} 2020$ and August $31^{\text {st }} 2020$ were retrospectively reviewed.

Results: During the last five months of the pandemic, a total of 387 patients were hospitalized and 309 of these patients underwent surgical procedures. 165 of the patients who underwent surgery were newly diagnosed malignancy patients. All patients who were hospitalized were subjected to a screening for COVID-19 during the preclinical, clinical and surgical period. In the preclinical period, five patients were found positive and were directed to COVID-19 treatment without hospitalization. In the clinical period, six patients were isolated by showing symptoms during the hospitalization period. Only one of these patients received surgical treatment. The remaining five patients underwent endoscopic and interventional procedures. In this process, COVID-19 positivity was detected in a total of five healthcare workers.
\end{abstract}

Conclusion: With this preclinical and clinical screening method, it is shown that a COVID-19 sterile environment can be provided by early detection of positive cases in both patients and healthcare workers. In this way, the possibility of surgical continuity was demonstrated.

Keywords: COVID-19, pandemic, pre-vaccination period, surgery

Cite this article as: Pişkin E, Çolakoğlu MK, Öter V, Özgün YM, Aydın O, Güven A, et al. How can surgical continuity be maintained during the COVID-19 pandemic? A quality improvement study in the pre-vaccination period. Turk J Surg 2021; 37 (2): 156-161

\section{Corresponding Author}

Erol Pişkin

E-mail:erol90279@gmail.com

Received: 26.01.2021

Accepted: 02.04.2021

Available Online Date: 10.05 .202

OCopyright 2021 by Turkish Surgical Society Available online at www.turkjsurg.com

DOI: $10.47717 /$ turkjsurg.2021.5226

\section{INTRODUCTION}

Respiratory track-related cases that emerged in the Wuhan province of China in December 2019 rapidly spread worldwide and caused radical changes in the field of health care together with all living spaces. Three months after the first appearance, along with the pandemic declaration of the World Health Organization (WHO) (1) on $11^{\text {th }}$ March 2020, the first cases started to emerge also in Turkey, and through a rapid response, the health system has been tried to be adapted to the pandemic period. The experience in China and then in Europe where the number of patients has seen a rapid rise contributed much to shape this adaptation. The increase in the need for hospital beds, intensive care beds and ventilators has led to the allocation of these resources for COVID-19 infected patients also in Turkey, and other non-compulsory health services have been delayed.

Surgeons and surgical patients have also been affected by this forced attitude. During the early phase of the pandemic, the results of the national survey that we conducted among the general surgeons in Turkey showed that a large majority of the surgeons were able to operate emergency cases, and elective cases were delayed as much as possible (2). Because of the intense and variable information 
flow during the first phase of the pandemic, approaches about malignant patients varied and the main point became whether to delay such patients or not.

Until today, the total number of infected patients in Turkey has been reported as 351413, the number of recovering patients as 306939, and the total number of deaths as 9445, and these numbers continue to increase (3). It is highly doubtful how long we can postpone the treatment of patients who need surgical treatment, and especially oncological patients, in a process that is uncertain when it will end, and it is a big question mark that needs to be answered. Surgical continuity should be ensured for these patients at some point.

In Ankara City Hospital, which has the largest bed number in Europe and the third largest in the world, during the COVID-19 pandemic period, the surgical management of oncological patients continues uninterruptedly from the first day of the process, and our center is a tertiary reference center where advanced digestive system surgery and liver transplantation are performed. A pre-clinic and clinical screening algorithm is established by our clinic with reflexes taken from the beginning of the pandemic period. This study aimed to define the reorganization of our department concerning methods with which we maintain surgical continuity in the center providing services as a pandemic hospital during the COVID-19 pandemic period by using a pre-clinic and clinical screening algorithm, and to report the results of all patients admitted to and hospitalized in our service in this fivemonth pre-vaccination period.

\section{MATERIAL and METHODS}

This retrospective quality improvement study is registered with the Ministry of Health form number 2020-08-18T14_08_35, and scientific research approval was obtained. Then, the study was evaluated and approved by the ethics board of our center. (Ethics board number: E1-20-1120)

Data of all patients who applied to surgical polyclinics and those admitted to the service for the need of surgical, interventional or endoscopic therapy between the date of April 01, 2020, when the first peak period started after the emergence of the initial cases, and August 31, 2020, including the second peak, were reviewed over digital records. After recording the number of month-to-month polyclinic and the number of patients admitted to and hospitalized in the service, the age, sex and reason for admission in the service for the patients who required admittance were evaluated. A screening algorithm was planned covering the pre-clinic and clinical period in order to minimize the COVID-19 risk (Figure 1), and all patients were subjected to that algorithm.

COVID-19 assessment procedure for the patients who required to be hospitalized for surgical, interventional or endoscopic therapy was completed in the polyclinics before the patients were admitted. During this process, primarily symptoms evaluation of the patients was conducted and they were physically examined. Patients who had anamnesis or any COVID-19 findings or suspects (fever $\geq 38^{\circ}$, dyspnea, respiration rate $>22$ /minute, general status disorder etc.) found during the examination were referred to the infectious diseases, and they were accepted to the service after their evaluation procedures had been completed. And for all patients who were not symptomatic, during the beginning of the pandemic process, radiological visualization with Thorax computed tomography (CT), and after the test became widespread, again for all patients, reverse transcriptase- polymerase chain (RT-PCR) test together with $C T$ was conducted. The patients who were found positive in one of the methods were referred again to the infectious diseases, and they were

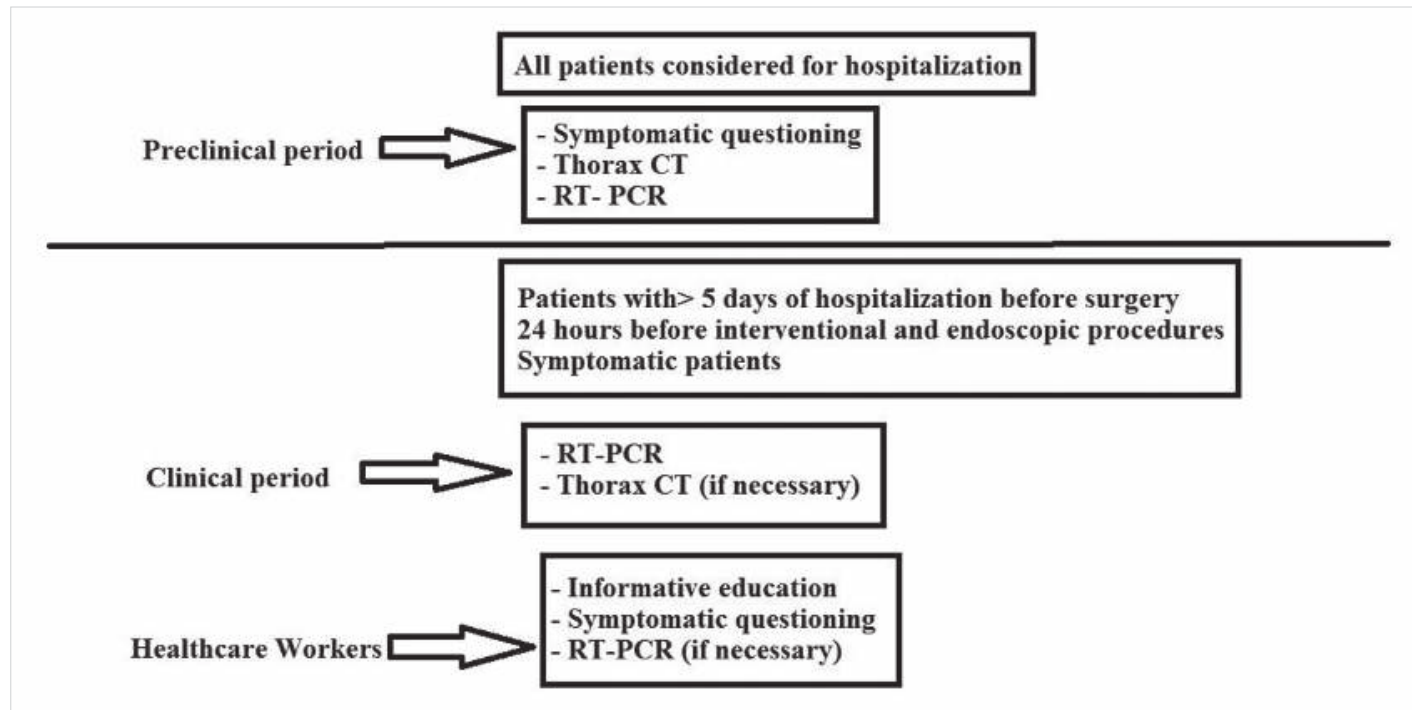

Figure 1. Preclinical and clinical screening algorithm. 
accepted to the service after their evaluation or treatment for COVID-19 was completed. Those patients who had negative results obtained from both of the methods were hospitalized. Informed consent forms were taken from the patient and patient's relatives both for the procedure to be delivered and for COVID-19 and related risks before hospitalization. RT-PCR test was repeated 24 hours before the procedure to be delivered (surgery, intervention, endoscopic) for those patients who had a hospitalization period longer than five days, and the planned procedures were delivered for the patients with negative results. The patients who had positive results were referred to the infectious diseases, and their treatments were started. For those patients who were assessed negative before hospitalization, but became symptomatic during the hospitalization period, RT-PCR and $C T$ were repeated when necessary. During this process, $C T$, RT-PCR and repeated RT-PCR results of all hospitalized patients were recorded. Treatment methods delivered for the patients were also recorded.

In addition to pre-operative COVID-19 evaluation, some changes were made in hospital and service policies. Working health staff and auxiliary staff were ensured to use masks, and personal protective equipment when necessary. Visitors' entrance was prevented and only one person was allowed for companion in compulsory cases. The patients and their companions, if any, were ensured to wear masks when health or auxiliary staff visited them. The patients with suspected findings were isolated and no one was allowed to visit them without personal protective equipment.

In our hospital, COVID-19 suspected or positive patients were followed in various services and isolated from other patients under the supervision of infectious diseases or pulmonary diseases services. The patients who had suspected findings during the hospitalization process or had test positive results were immediately transferred to these services, and their follow-ups were performed at these services when necessary. For those cases who required urgent surgery or known to be COVID-19 positive were operated in separate operation rooms by taking measures and again followed up at services allocated to COVID-19.

Through this defined algorithm, the therapies of the patients continued as both their pre-operative check-out were conducted and a COVID-19 negative environment was tried to be creat- ed. During this five-month period, whether the surgery service and operation room staff had COVID-19 positivity was recorded by examining the staff records.

\section{RESULTS}

A total of 5185 outpatients were admitted to our surgical polyclinics between April 1 ${ }^{\text {st }}, 2020$ and August 31 ${ }^{\text {st }}, 2020$. After the evaluations made for these patients, 392 (232-males and 160-females) of them were hospitalized. Median age of the patients agreed to be hospitalized was $53.06 \pm 15.14$ (17-84 ages). While 165 of the patients (42\%) were hospitalized for their newly diagnosed malignancy, the other patients were either previously operated malignant or newly diagnosed benign patients. While great majority of the cases were desired to be hospitalized for diagnosis of lower gastrointestinal system (GIS) diseases $(n=80$, 20.4\%), the number of the upper GIS, hepato pancreaticobiliary system, liver transplantations and other (cholelithiasis, hydatid cyst etc.) diseases were respectively as 58 (14.7\%), 57 (14.5\%), 35 (8.9\%) and 162 (41.2\%).

While PCR test was not very widespread during April and May, most of the assessments were made through $C T$ evaluation, both methods were used together during June, July and August. During COVID-19 evaluation of the cases, before hospitalization during the polyclinic stage, COVID-19 positivity was detected in a total of five (3\%) patients with CT radiological examination and RT-PCR test. CT and RT-PCR results of these five patients are presented in Table 1. According to this, while in all five patients PCR positivity was detected, CT findings appeared only in three patients. Those patients detected positive were referred to the infectious diseases department, and first their COVID-19 treatments were completed and then, as the infectious diseases department approved, their re-applications were accepted. The remaining 387 patients were hospitalized in services.

While 309 (79.8\%) of the hospitalized patients had surgical intervention, 26 received (6.7\%) cendoscopic intervention (including endoscopic retrograde colangiopancreaticography) and 22 (5.6\%) interventional radiology. Thirty patients (7.7\%) were followed up on medical treatment. Most of the surgical interventions were conducted for hospitalized oncological cases, five patients had liver transplantations (four living donors, one cadaveric). From the RT-PCR tests taken and repeated during

Table 1. Computed tomography (CT) and RT-PCR results of the patients with COVID-19 + detected in pre-clinic evaluation

\begin{tabular}{|l|c|c|}
\hline & CT & RT-PCR \\
\hline Patient 1 & Findings consistent with COVID-19 & Positive \\
\hline Patient 2 & Findings consistent with COVID-19 & Positive \\
\hline Patient 3 & No findings consistent with COVID-19 & Positive \\
\hline Patient 4 & No findings consistent with COVID-19 & Positive \\
\hline Patient 5 & Findings consistent with COVID-19 & Positive \\
\hline
\end{tabular}


Table 2. Number of outpatient clinic patients, number of hospitalized patients, treatment and COVID-19 status

\begin{tabular}{|c|c|c|c|c|c|c|}
\hline & April & May & June & July & August & Total \\
\hline Outpatient clinic patients (n) & 414 & 564 & 1530 & 1431 & 1246 & 5185 \\
\hline Hospitalized patients (n) & 19 & 37 & 106 & 136 & 94 & 392 \\
\hline \multicolumn{7}{|l|}{ Treatment method (n) } \\
\hline Surgery & 12 & 28 & 75 & 113 & 81 & 309 \\
\hline Endoscopy & 0 & 4 & 7 & 2 & 0 & 13 \\
\hline ERCP & 0 & 1 & 8 & 1 & 3 & 13 \\
\hline Interventional & 3 & 3 & 4 & 8 & 4 & 22 \\
\hline Medical & 3 & 0 & 9 & 12 & 6 & 30 \\
\hline Number of COVID-19 positives before hospitalization & 1 & 1 & 3 & 0 & 0 & 5 \\
\hline Number of $\mathrm{CT}$ positive cases & 1 & 1 & 1 & 0 & 0 & - \\
\hline Number of RT-PCR positive cases & 1 & 1 & 3 & 0 & 0 & - \\
\hline Number of RT-PCR positive cases after hospitalization & 1 & 1 & 0 & 2 & 2 & 6 \\
\hline
\end{tabular}

the hospitalization process, positivity was detected only in six patients (1.5\%). The test was repeated in these six patients because of resistant fever. After the identification of positivity, these patients were also referred to the infectious diseases department and their follow-ups and treatments were completed. The month-to-month hospitalization numbers, treatments delivered and COVID-19 statuses of the hospitalized patients are presented in Table 2.

During this five-month period, when the service and operation room physician and health staff records are examined, COVID-19 positivity was detected only in one operation room nurse, two service nurses and two physicians. The staff continued their duties after their treatments were completed and approval was obtained from infectious diseases department. No COVID-19 related mortality was observed in patients with detected COVID-19 positivity.

\section{DISCUSSION}

The COVID-19 pandemic affecting the entire world has also caused important changes to be made in the health system. Because of increasing intensive care and ventilator needs and personal protective equipment requirements, as the majority of the hospital resources had to be used for these patients, dilemmas were faced with ways of managing the treatments of other patients and especially of oncological cases. Leading surgical associations in the world have declared guidelines during the beginning of the pandemic about which oncological patients' surgical treatments may be delayed in which conditions or to which alternative treatments they may be led (4-9). While the first reason for such a desire for delay was adequate and correct management of hospital resources, the real fear stemmed from the fact that mortality is higher in oncological patients infected by COVID-19 (10). During the pandemic, we have published a review about managing digestive system cancers (11). Howev- er, the ongoing pandemic process had gone beyond such durations of delays that were seen as possible in these guidelines, and is still ongoing. Therefore, at some point, it seems no more possible to delay the surgical treatments of the oncological patients, and maintenance of surgical continuity is a requirement for not interrupting their treatment conditions.

Our study showed that surgical continuity can be achieved by presenting the number of patients, number of hospitalizations, treatment services provided and COVID-19 positive status of the patients during the pandemic period. As a reflex to the outbreak, the number of admitted patients decreased in April and May that refer to the beginning of the process; however, after completing adaptation and reorganization, the numbers returned to normal in June and July. We think that there are two basic conditions for these conditions to be achieved.

The first basic condition to manage surgical continuity, as defined in the guidelines, is to have enough resources. Surgical and especially oncological patients are the ones who may need intensive care or ventilator after the post-operative period. Also, for the health staff who will assume their care, adequate personal protective equipment should be provided. This may create problems both in COVID-19 and oncological treatment centers. For this reason, in the centers where surgical continuity should be maintained, separate and adequate operation room, intensive care and personal protective equipment support should be provided for such patients.

The second condition to manage surgical continuity is to provide a COVID-19 negative environment especially for oncological patients. Therefore, we believe that patients should be subjected to a detailed evaluation in terms of COVID-19 before hospitalization. For this aim, a triple evaluation was performed in polyclinic services for the patients. Although no findings were found in the patients planned to be hospitalized in their symptomatic interro- 
gation or physical examination, positivity was detected in five patients. However, in two patients who were to be hospitalized, the test was repeated for resistant fever and positivity was identified. For this reason, symptomatic follow-ups of all patients should be closely observed. Although the sensitivity and specificity of the $C T$ and RT-PCR analyses show variances, it is known that using both methods together reduces the rate of false negativity (12) As during the beginning of the pandemic process PCR usage was not widespread, CT was used alone but after then, by using both methods together, admittance of COVID-19 positive patients in the service was prevented at an early stage and they were referred to the infectious diseases department.

In order to maintain a COVID-19 negative environment, in addition to the health staff, the patients and their relatives were required to wear masks, outside of their personal areas and when health staff entered in their rooms. No companions were allowed beside the patients when it was not necessary. Also, the mobilization of the patients and their relatives out of the service was kept limited. Despite the measures taken during pre-hospitalization and hospitalization, during hospitalization periods, COVID-19 positivity was detected in six patients, and these six patients were the ones with long hospitalization periods. Only one of them had surgical treatment, and the other five patients had endoscopy or interventional treatment. For all six patients, PCR test was repeated for resistant fever and positivity was shown. These patients were isolated and then, they were referred to the infectious diseases department and their treatments were followed up there. For this reason, we think that PCR technique should be repeated, 24 hours before each invasive intervention to be made, for patients with longer hospitalization and for patients becoming symptomatic.

Although there are adequate resources and COVID-19 negative environment is maintained, as the ability of the disease to infect is high, the patients and the health staff should be closely followed up. One of the limitations of this study is that no systematic evaluation is made about the COVID-19 status of the health employees. COVID-19 positivity was detected only in one operation room nurse, two service nurses and two physicians, and after completing the treatment and approval of the infectious diseases department, service provision continued. However we do not know whether these employees caught the disease during the working process or outside the hospital. The other limitation is that the study is a retrospective evaluation. This study evaluates clinical management in the pre-vaccination period. COVID-19 vaccination started to be performed to healthcare workers in the second week of January, 2021. Not enough time has yet passed to see what might change clinically after vaccination. For this reason, we think that our recommendations may be valuable in surgical clinic management, even after vaccination, until we all enter a full normalization process.

\section{CONCLUSION}

During the ongoing pandemic process, it is not possible to delay the surgical treatment of the oncological patients forever. Their surgical treatments should continue by taking the risk of contamination for these patients. In order to do this, the center should have adequate resources and a COVID-19 negative environment should be maintained. Surgical continuity is only possible when these conditions are met. In cases where these conditions cannot be provided, oncological patients should be directed to appropriate centers.

Ethics Committee Approval: The ethical approval for this study was obtained from Ankara City Hospital No.1 Clinical Research Ethics Committee Board (Decision No: E1-20-1120, Date: 02.09.2020).

Peer-review: Externally peer-reviewed.

Author Contributions: Concept - E.P., V.Ö., M.K.C.; Design - E.P., V.Ö., M.K.C.; Supervision - M.M.Ö., E.B.B., A.A.S.; Materials - Y.M.Ö., O.A.; Data Collection and/or Processing - Y.M.Ö., O.A., A.G.; Literature Review - M.K.C., V.Ö.; Writing Manuscript - E.P., M.K.C.; Critical Reviews - E.B.B., M.M.Ö., A.A.S.

Conflict of Interest: The authors declare that they have no conflict of interest.

Financial Disclosure: The authors declared that this study has received no financial support.

\section{REFERENCES}

1. World Health Organization (WHO). Rolling updates on coronavirus disease (COVID-19). Available from: https://www.who.int/emergencies/diseases/novel-coronavirus-2019/events-as-they-happen (Accessed date: 30.03.2020). [CrossRef]

2. Colakoglu MK, Ozgün YM, Pişkin E, Bostancı EB, Ozmen MM. The attitude of Turkish general surgeons during the COVID-19 pandemic: results of "general surgery COVID-19 pandemic attitude survey". Turk J Surg 2020; 36 (2): 137-146. [CrossRef]

3. Republic of Turkey, Ministry of Health. Current status in Turkey. Available from: https://covid19.saglik.gov.tr/?lang=en-US (Accessed date: 21.10.2020). [CrossRef]

4. American College of Surgeons (FACS). COVID-19 guidelines for triage of colorectal cancer patients. Available from: https://www.facs.org/covid-19/clinical-guidance/elective-case/colorectal-cancer [CrossRef]

5. Society for Surgical Oncology (SSO). Resource for management options of colorectal cancer during COVID-19. Available from: https:// www.surgonc.org/wp-content/uploads/2020/03/Colorectal-Resource-during-COVID-19-3.23.20.pdf. [CrossRef]

6. Society for Surgical Oncology (SSO). Resource for management options of Gl and HPB cancers during COVID-19. Available from: https:// www.surgonc.org/wp-content/uploads/2020/04/Gl-and-HPBResource-during-COVID-19-4.6.20.pdf. [CrossRef]

7. Society of American Gastrointestinal and Endoscopic Surgeons (SAGES). Recommendations regarding surgical management of gastric cancer patients during the response to the COVID-19 crisis. Available from: $\quad$ https://WwW.sages.org/sages-recommendations-surgicalmanagement-gastric-cancer-COVID-19-crisis/ (Accessed date: 2020). [CrossRef] 
Society of American Gastrointestinal and Endoscopic Surgeons (SAGES). AHPBA recommendations regarding surgical management of hpb can-cer patients during the response to the COVID-19 crisis. Available from: $h t t p s: / / w w w . s a g e s . o r g / s a g e s-a h p b a-r e c o m m e n d a t i o n s-$ surgical-management-of-hpb-cancer-COVID-19/ (Accessed date: 2020). [CrossRef]

9. Society of American Gastrointestinal and Endoscopic Surgeons (SAGES). Recommendations regarding surgical management of Colorectal cancer patients during the response to the COVID-19 Crisis. Available from: https://www.sages.org/recommendations-surgicalmanagement-colorectal-cancer-COVID-19/ (Accessed date: 2020) [CrossRef]
10. Liang W, Guan W, Chen R, Wang W, Li J, Xu K, et al. Cancer patients in SARS-CoV-2 infection: a nationwide analysis in China. Lancet Oncol 2020; 21(3): 335-7. [CrossRef]

11. Colakoglu MK, Oter V, Bostancı EB, Ozmen MM, Saribeyoglu K. Surgical management of digestive system cancers during the coronavirus disease 2019 pandemic: review of general suggestions. Turk J Surg 2020; 36(2): 121-131. [CrossRef]

12. Ai T, Yang Z, Hou H, Zhan C, Chen C, Wenzhi L, et al. Correlation of Chest CT and RT-PCR testing for Coronavirus Disease 2019 (COVID-19) in China: a report of 1014 cases. Radiology 2020; 296(2): 32-40. [CrossRef]

\section{ORIJINAL ÇALIŞMA-ÖZET}

\section{COVID-19 salgını sırasında cerrahi devamlılık nasıl korunabilir? Aşılama öncesi dönemde bir kalite iyileştirme çalışması}

Erol Pişkin ${ }^{1}$, Muhammet Kadri Çolakoglu ${ }^{1}$, Volkan Öter ${ }^{1}$, Yiğit Mehmet Özgün ${ }^{1}$, Osman Aydın ${ }^{1}$, Alper Güven ${ }^{1}$, Aziz Ahmet Sürel ${ }^{2}$, M. Mahir Özmen ${ }^{3,4,5}$, Erdal Birol Bostancl ${ }^{1}$

1 Sağlık Bilimleri Üniversitesi Ankara Şehir Hastanesi, Gastrointestinal Cerrahi Kliniği, Ankara, Türkiye

${ }^{2}$ Sağlık Bilimleri Üniversitesi Ankara Şehir Hastanesi, Genel Cerrahi Kliniği, Ankara, Türkiye

${ }^{3}$ İstinye Üniversitesi Tıp Fakültesi, Cerrahi Anabilim Dalı, İstanbul, Türkiye

${ }^{4}$ Liv Hastaneleri, Genel Cerrahi, Ankara, Türkiye

${ }^{5}$ Ankara Numune Eğitim ve Araştırma Hastanesi, Cerrahi, Ankara, Türkiye

\section{ÖZET}

Giriş ve Amaç: COVID-19 salgını sırasında, elektif ameliyatların çoğu ertelenmek zorunda kalmıştır. Ancak kanser hastalarının cerrahi tedavisini uzun süre ertelemek mümkün değildir. Bu çalışmanın amacı, gastrointestinal sistem cerrahisi operasyonlarının gecikmeden nasıl yönetildiğini ve çalışan güvenliğinin nasıl sağlanacağını son beş ayın sonuçlarıyla birlikte ortaya koymaktır. Bu amaçla pre-klinik ve klinik bir tarama sistemi oluşturuldu.

Gereç ve Yöntem: Polikliniğimize 1 Nisan 2020 ile 31 Ağustos 2020 tarihleri arasında başvuran hastaların verileri geriye dönük olarak incelendi ve tarama sistemi oluşturuldu.

Bulgular: Son beş aylık pandemi döneminde toplam 387 hasta kliniğimize yatııılı ve bu hastaların 309' una cerrahi işlem uygulandı. Ameliyat geçiren hastaların $165^{\prime}$ i yeni tanı konulmuş malignite hastasıydı. Hastaneye yatıııan tüm hastalar yatış öncesi, yatış sonrası ve cerrahi dönemde COVID-19 taramasına tabi tutuldu. Klinik öncesi dönemde beş hastanın testi pozitif bulunarak hastaneye yatmadan COVID-19 tedavisine yönlendirildi. Klinik dönemde altı hasta yatış süresi boyunca semptomları olması üzerine izole edildi. Bu hastalardan sadece bir tanesine cerrahi tedavi uygulanmıştı. Kalan beş hastaya endoskopik ve girişimsel prosedürler uygulandı. Bu süreçte toplam beş sağlık çalışanında COVID-19 pozitifliği tespit edildi.

Sonuç: Bu pre-klinik ve klinik tarama yöntemi ile hem hastaların hem de sağlık çalışanlarının pozitif vakalarının erken tespiti ile COVID-19 steril ortamının sağlanabileceği gösterilmiştir. Bu şekilde cerrahi devamlılı̆ın olabileceği gösterilmiştir.

Anahtar Kelimeler: COVID-19, pandemi, aşılama öncesi dönem, cerrahi

Doi: $10.47717 /$ turkjsurg.2021.5226 